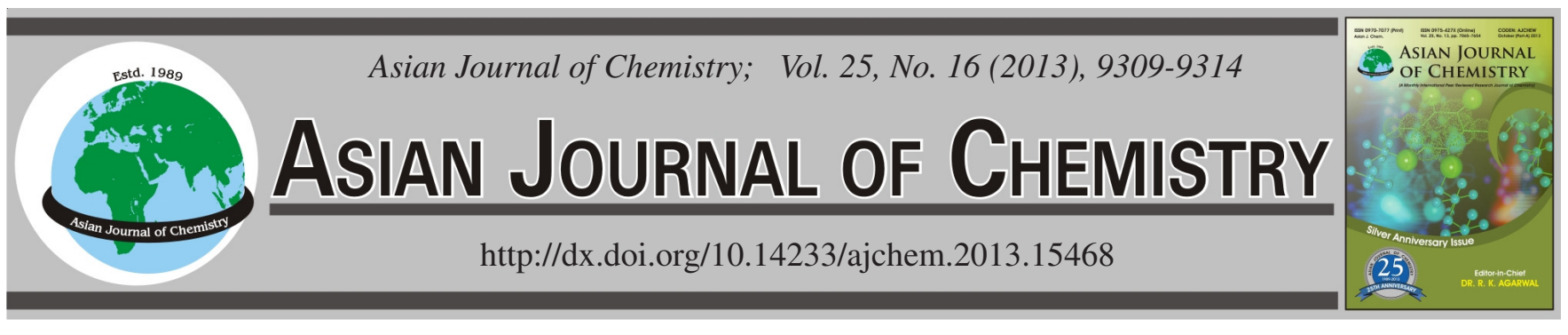

\title{
Removal of Silica from Cooling Water by Electrocoagulation: A Comprehensive and Systematic Study Using Response Surface Methodology
}

\author{
S.L. ZHI, S.T. ZHANG ${ }^{*}$ and X.B. LU
}

School of Environmental Science and Engineering, Tianjin University, Tianjin, China

*Corresponding author: Tel: +86 22 87402148; E-mail: zhangst@tju.edu.cn; zhisuli87@163.com

\begin{abstract}
To effectively recycle and reuse water, the prevention of silica deposits become an urgent requirement in many industries. The laboratory scale electrocoagulation system was investigated to remove silica. And the interactions between all the influencing factors were analyzed not only for silica removal efficiency, but also for energy consumption, electrode consumption and sludge production. The values of adj $\mathrm{R}^{2}$ of the models were 0.9315 for silica removal efficiency, 0.9768 for energy consumption, 0.7633 for electrode consumption and 0.9698 for sludge production, respectively, which indicated that all the models were significant. The optimal conditions were $60 \mathrm{mg} / \mathrm{L}$ initial silica concentration, $2.50 \mathrm{~cm}$ interelectrode distance, 40.47 min reaction time, $7.50 \mathrm{pH}$ value, $3.89 \mathrm{~mA} / \mathrm{cm}^{2}$ current density and $4 \mathrm{~cm}$ submerged height of electrode, under which $85.147 \%$ silica removal efficiency, $1.455 \mathrm{KWh} / \mathrm{m}^{3}$ energy consumption, $0.0389 \mathrm{~kg} / \mathrm{m}^{3}$ electrode consumption and $0.242 \mathrm{~kg} / \mathrm{m}^{3}$ sludge production were obtained and the desirability was 0.831 for the optimal conditions. By performing the optimum conditions, $83.243 \%$ silica removal efficiency, $1.466 \mathrm{KWh} / \mathrm{m}^{3}$ energy consumption, $0.0400 \mathrm{~kg} / \mathrm{m}^{3} \mathrm{electrode}$ consumption and $0.245 \mathrm{~kg} / \mathrm{m}^{3}$ sludge production were obtained.
\end{abstract}

Key Words: Electrocoagulation, Silica, Response surface methodology, Optimization.

\section{INTRODUCTION}

With the increasing water pollution, the serious scarcity of water and increasing pressure for water conservation, the recycle and reuse of water have attracted more and more attention by the operators in different industries ${ }^{1}$. Surprisingly, $70 \%$ of industrial water is used as cooling water. However, cooling water recycling can lead to concentration of dissolved species to a critical point of precipitation of insoluble mineral salts $^{2}$. Silica scale is a big technical challenge and a big financial burden for industrial operators for it is a dense and rigid form. It can reduce boiler power output by $10-20 \%$ and thermal efficiency by $10 \%$, plug the pipeline $\mathrm{e}^{7-9}$ and make more shutdowns ${ }^{2}$. Thus, it is urgent to remove silica from cooling water in order to recycle and reuse water.

Prevention of silica scale commonly follows two distinct approaches. The first one is adding anti-scalant in water to inhibit scale formation and the other is to install a pretreatment process to reduce the silica concentration before application ${ }^{10}$. The choice of anti-scalant is highly dependent on the processes and congurations, which makes this approach a little bit precarious. The pretreatment of cooling water include chemical precipitation $^{11,12}$ and silica-gel seeding ${ }^{13}$. The optimum dosage of precipitant depends on the silica concentration and the back- ground matrix of the solution, as well as the required extent of silica reduction. Pretreatment by silica-gel seeding intends to provide a seeding surface on which silica monomers deposit, thereby removing dissolved silica from solution. However, this method was ineffective when silica polymers formed in the solution under highly supersaturated conditions.

Recently, electrocoagulation technology is investigated for water purification and wastewater treatment as a promising technology $y^{14-17}$. And sporadic studies have reported that it can be used as a pretreatment method for silica removal. Walter Den and Chia-Jung Wang ${ }^{11}$ used electrocoagulation as a pretreatment process to treat the source brackish water containing $100 \mathrm{mg} / \mathrm{L}$ silica for reverse osmosis process and the extent of flux decline was markedly improved. Gelover-Santiago et al. ${ }^{18}$ tested three electrochemical systems to remove silica in makeup water for cooling tower and the most advantageous system is the one with both aluminium electrodes working with direct current. Liao et al. ${ }^{19}$ reported the effectiveness of electrocoagulation using iron and aluminium electrodes for treating cooling tower blowdown water containing dissolved silica, $\mathrm{Ca}^{2+}$ and $\mathrm{Mg}^{2+}$ with different initial $\mathrm{pH}$ values and additives. However, no one studied the effect of design and operation factors of the electrocoagulation process to reduce power consumption, electrode consumption and sludge production in the field 
of silica removal from cooling water. And few study reported the interrelation of the influencing factors simultaneously to recycle cooling water.

The paper presents a systematic study of the factors which affect the electrocoagulation process using response surface methodology. The optimal condition was obtained to maximize silica reduction efficiency and minimize energy consumption, electrode consumption and sludge production. The study was proposed as an economical and efficient technology for silica removal from cooling water.

\section{EXPERIMENTAL}

Setup and procedure: Fig. 1 shows an overview of experimental set-up. The electrocoagulation reactor is made of plexiglass with a dimension of $8 \mathrm{~cm} \times 20 \mathrm{~cm} \times 16 \mathrm{~cm}(\mathrm{~W} \times$ $\mathrm{L} \times \mathrm{H})$ and the effective volume is $1.5 \mathrm{~L}$. The two aluminium electrodes were prepared with identical size of $18 \mathrm{~cm} \times 18 \mathrm{~cm}$ and the effective area is adjusted by changing the submerged height of the electrode. Before using, the impurities on the surfaces of aluminium were removed with sand paper, then dipped for $5 \mathrm{~min}$ in a solution which was mixed $\mathrm{HCl}$ aqueous solution $(35 \%, 50 \mathrm{~mL})$ with aqueous solution of hexamethylenetetramine $(2.8 \%, 100 \mathrm{~mL})$ together ${ }^{20}$. Electrical current is provided by a manually digital DC power supply. Artificial water containing different concentrations of silica is treated for different time, under different operating conditions. During the experiments, the initial $\mathrm{pH}$ of solution is adjusted to desirable values using diluted $\mathrm{NaOH}$ or $\mathrm{H}_{2} \mathrm{SO}_{4}$ solution. After each run, the samples were filtered with $0.45 \mu \mathrm{m}$ membrane to separate the solids and then they were dried at $30^{\circ} \mathrm{C}$ for $48 \mathrm{~h}$ to determine the sludge production ${ }^{21}$.

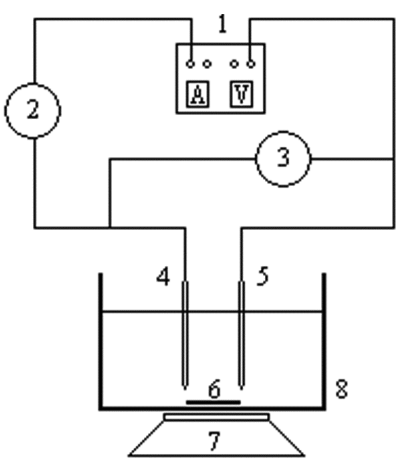

Fig. 1. Schematic diagram of experimental set-up. 1. Digital DC power supply; 2. Digital amperemeter; 3. Digital voltmeter; 4,5 Electrodes; 6. Magnetic bar; 7. Magnetic stirring controller; 8 . Water tank

Calculation method: The removal efficiency of silica is calculated as

$$
\eta(\%)=\frac{\mathrm{C}_{\mathrm{i}}-\mathrm{C}_{\mathrm{f}}}{\mathrm{C}_{\mathrm{i}}} \times 100
$$

where $\mathrm{C}_{\mathrm{i}}$ is the initial silica concentration $(\mathrm{mg} / \mathrm{L})$ and $\mathrm{C}_{\mathrm{f}}$ is the final silica concentration $(\mathrm{mg} / \mathrm{L})$.

The energy consumption ENC $\left(\mathrm{KWh} / \mathrm{m}^{3}\right)$ is calculated from

$$
\mathrm{ENC}=\frac{\sum\left(\mathrm{U} \times \mathrm{I} \times \mathrm{t}^{\prime}\right)}{\mathrm{V}}
$$

where $U$ is the voltage $(V), I$ is the electrolysis current $(A), t$ ' is the time interval (h) and $\mathrm{V}$ is the volume of the solution treated (it is $1.5 \mathrm{~L}$ ).

The electrode consumption ELC $\left(\mathrm{kg} / \mathrm{m}^{3}\right)$ was obtained by weighing the quality before and after the experiment and expressed as follows:

$$
\mathrm{ELC}=\frac{\left(\mathrm{m}-\mathrm{m}^{\prime}\right)}{\mathrm{V}}
$$

where $\mathrm{m}$ and $\mathrm{m}$ ' are the weight of electrode before and after the experiment $(\mathrm{g})$ and $\mathrm{V}$ is the volume of the solution treated.

The sludge production Ws $\left(\mathrm{kg} / \mathrm{m}^{3}\right)$ is calculated from

$$
\mathrm{Ws}=\frac{\mathrm{M}}{\mathrm{V}}
$$

where $\mathrm{M}$ is the weight of sludge produced from the experiments $(\mathrm{g})$ and $\mathrm{V}$ is the volume of the solution treated.

Design and optimization: The electrolysis experiments were carried out according to a five-level, six-factor central composite rotatable design (CCD) using Design-Expert 7.0. Each independent variable was coded at five levels between -2 and +2 at the ranges according to the preliminary experiments, where the independent variable were initial silica concentration $\mathrm{C}_{0}\left(\mathrm{x}_{1}=20-100 \mathrm{mg} / \mathrm{L}\right)$, interelectrode distance $\mathrm{d}\left(\mathrm{x}_{2}=0.5-2.5 \mathrm{~cm}\right)$, reaction time $\mathrm{t}\left(\mathrm{x}_{3}=15-75 \mathrm{~min}\right)$, initial $\mathrm{pH}$ $\left(\mathrm{x}_{4}=4.5-10.5\right)$, current density i $\left(\mathrm{x}_{5}=2-6 \mathrm{~mA} / \mathrm{cm}^{2}\right)$ and submerged height $\mathrm{h}\left(\mathrm{x}_{6}=4-8 \mathrm{~cm}\right)$. Table- 1 shows run number and experimental conditions of the runs arranged by the CCD. Performance of the process was evaluated by analyzing the responses: silica removal efficiency, energy consumption, electrode consumption and sludge production.

The quadratic model which also includes the linear model for predicting the optimal point is expressed as:

$$
\mathrm{y}_{\mathrm{i}}=\mathrm{b}_{0}+\sum_{\mathrm{i}} \mathrm{b}_{\mathrm{i}} \mathrm{x}_{\mathrm{i}}+\sum_{\mathrm{i}} \mathrm{b}_{\mathrm{ii}} \mathrm{x}_{\mathrm{i}}^{2}+\sum_{\mathrm{i}} \sum_{\mathrm{j}} \mathrm{b}_{\mathrm{ij}} \mathrm{x}_{\mathrm{i}} \mathrm{x}_{\mathrm{j}}
$$

where $y_{i}$ is the predicted response, $b_{0}$ is the interception coefficient, $b_{i}$ is the linear term, $b_{i i}$ is the quadratic term and $b_{i j}$ is the interaction term.

Validation of the model: In the case of a composite design, the validation of the model is carried out by an appropriate analysis of variance (ANOVA). The model is considered adequate if the variance due to regression is significantly different from the total variance. 'Statistica' software is performed for regression and graphical analysis of data obtained. The optimum conditions is studied by analyzing the response surface plots.

\section{RESULTS AND DISCUSSION}

Regression coefficients estimating and interaction of variables analyzing: The regression coefficients and corresponding $\mathrm{F}$ and $\mathrm{P}$ values for silica removal efficiency, energy consumption, electrode consumption and sludge production are given in Tables 2-5. For silica removal efficiency, reaction time, initial $\mathrm{pH}$, current density, the interaction between reaction time and initial $\mathrm{pH}$, the interaction of initial silica concentration, the interaction of reaction time, the interaction of initial $\mathrm{pH}$ and the interaction of current density are significant model terms. For energy consumption, interelectrode 
TABLE-1

ACTUAL DESIGN OF EXPERIMENTS AND RESPONSES FOR ELECTROCOAGULATION PROCESS

\begin{tabular}{|c|c|c|c|c|c|c|c|c|c|c|}
\hline Run No. & $\mathrm{x}_{1}$ & $\mathrm{X}_{2}$ & $\mathrm{X}_{3}$ & $\mathrm{X}_{4}$ & $\mathrm{X}_{5}$ & $\mathrm{x}_{6}$ & $\mathrm{y}_{1}: \eta$ & $\mathrm{y}_{2}: \mathrm{ENC}$ & $\mathrm{y}_{3}: \mathrm{ELC}$ & $\mathrm{y}_{4}: \mathrm{Ws}$ \\
\hline 1 & 60 & 1.5 & 45 & 10.5 & 4 & 6 & 100 & 2.30 & 0.10 & 0.51 \\
\hline 2 & 60 & 1.5 & 45 & 7.5 & 2 & 6 & 79.30 & 0.67 & 0.05 & 0.21 \\
\hline 3 & 80 & 2.0 & 60 & 6 & 5 & 5 & 100 & 3.66 & 0.12 & 0.54 \\
\hline 4 & 60 & 0.5 & 45 & 7.5 & 4 & 6 & 95.06 & 0.96 & 0.09 & 0.40 \\
\hline 5 & 40 & 1.0 & 60 & 9 & 5 & 7 & 100 & 2.88 & 0.11 & 0.56 \\
\hline 6 & 60 & 1.5 & 45 & 7.5 & 4 & 8 & 97.09 & 3.13 & 0.12 & 0.53 \\
\hline 7 & 80 & 1.0 & 60 & 9 & 3 & 7 & 100 & 1.28 & 0.11 & 0.49 \\
\hline 8 & 60 & 1.5 & 45 & 7.5 & 4 & 6 & 99.23 & 2.26 & 0.09 & 0.39 \\
\hline 9 & 60 & 1.5 & 45 & 7.5 & 4 & 6 & 99.06 & 2.21 & 0.09 & 0.40 \\
\hline 10 & 60 & 2.5 & 45 & 7.5 & 4 & 6 & 100 & 3.26 & 0.11 & 0.39 \\
\hline 11 & 60 & 1.5 & 45 & 4.5 & 4 & 6 & 73.89 & 1.99 & 5.45 & 0.37 \\
\hline 12 & 40 & 1.0 & 30 & 9 & 5 & 5 & 100 & 1.44 & 0.06 & 0.30 \\
\hline 13 & 80 & 1.0 & 60 & 6 & 5 & 7 & 100 & 3.03 & 0.17 & 0.77 \\
\hline 14 & 60 & 1.5 & 45 & 7.5 & 4 & 4 & 95.12 & 1.47 & 0.05 & 0.27 \\
\hline 15 & 40 & 2.0 & 30 & 9 & 5 & 7 & 100 & 3.66 & 0.08 & 0.41 \\
\hline 17 & 60 & 1.5 & 45 & 7.5 & 4 & 6 & 99.15 & 2.27 & 0.10 & 0.39 \\
\hline 18 & 60 & 1.5 & 45 & 7.5 & 4 & 6 & 99.20 & 2.24 & 0.08 & 0.39 \\
\hline 19 & 80 & 2.0 & 60 & 9 & 3 & 5 & 95.81 & 0.91 & 0.07 & 0.38 \\
\hline 20 & 40 & 1.0 & 30 & 6 & 3 & 5 & 59.30 & 0.55 & 0.05 & 0.15 \\
\hline 21 & 40 & 2.0 & 60 & 9 & 5 & 5 & 100 & 3.92 & 0.09 & 0.45 \\
\hline 22 & 20 & 1.5 & 45 & 7.5 & 4 & 6 & 92.08 & 2.12 & 0.09 & 0.39 \\
\hline 23 & 60 & 1.5 & 15 & 7.5 & 4 & 6 & 62.04 & 0.70 & 0.03 & 0.14 \\
\hline 24 & 80 & 1.0 & 30 & 6 & 5 & 5 & 70.42 & 1.08 & 0.05 & 0.28 \\
\hline 25 & 40 & 2.0 & 60 & 6 & 3 & 5 & 84.84 & 1.85 & 0.06 & 0.30 \\
\hline 26 & 60 & 1.5 & 75 & 7.5 & 4 & 6 & 100 & 3.62 & 0.15 & 0.64 \\
\hline 27 & 100 & 1.5 & 45 & 7.5 & 4 & 6 & 85.82 & 1.73 & 0.08 & 0.42 \\
\hline 28 & 80 & 2.0 & 30 & 9 & 3 & 7 & 86.39 & 1.58 & 0.05 & 0.28 \\
\hline 29 & 40 & 2.0 & 30 & 6 & 3 & 7 & 69.32 & 1.35 & 0.05 & 0.21 \\
\hline 30 & 60 & 1.5 & 45 & 7.5 & 6 & 6 & 97.63 & 4.67 & 0.15 & 0.59 \\
\hline 31 & 40 & 1.0 & 60 & 6 & 3 & 7 & 95.26 & 1.59 & 0.09 & 0.43 \\
\hline
\end{tabular}

distance, reaction time, current density, submerged height of electrode, the interaction between initial silica concentration and initial $\mathrm{pH}$, the interaction between interelectrode distance and current density, the interaction between interelectrode distance and submerged height of electrode, the interaction between reaction time and initial $\mathrm{pH}$, the interaction between reaction time and current density and the interaction of initial silica concentration are significant model terms. For electrode consumption, reaction time, current density and submerged height of electrode are significant model terms. For sludge production, reaction time, initial $\mathrm{pH}$, current density, submerged height of electrode, the interaction between initial silica concentration and reaction time, the interaction between reaction time and current density, the interaction between reaction time and initial $\mathrm{pH}$ and the interaction between initial $\mathrm{pH}$ and current density are significant model terms. It can be seen from the above analysis that reaction time and current density are the two main factors affecting the four responses severly.

According to the experimental results, the regression equations relating to the four responses are developed and given in eqns. 6-9. It is noteworthy that the predicting model is a linear one for electrode consumption.

$$
\begin{aligned}
& \mathrm{y}_{1}=97.85-1.56 \mathrm{x}_{1}+1.23 \mathrm{x}_{2}+9.49 \mathrm{x}_{3}+6.53 \mathrm{x}_{4}+4.58 \mathrm{x}_{5} \\
& +1.74 \mathrm{x}_{6}+0.81 \mathrm{x}_{1} \mathrm{x}_{2}+2.04 \mathrm{x}_{1} \mathrm{x}_{3}-0.43 \mathrm{x}_{1} \mathrm{x}_{4}+0.13 \mathrm{x}_{1} \mathrm{x}_{5}
\end{aligned}
$$

$$
\begin{aligned}
& +0.030 \mathrm{x}_{1} \mathrm{x}_{6}-0.84 \mathrm{x}_{2} \mathrm{x}_{3}-0.11 \mathrm{x}_{2} \mathrm{x}_{4}+0.16 \mathrm{x}_{2} \mathrm{x}_{5}+1.01 \mathrm{x}_{2} \mathrm{x}_{6} \\
& -4.43 \mathrm{x}_{3} \mathrm{x}_{4}-2.00 \mathrm{x}_{3} \mathrm{x}_{5}+0.48 \mathrm{x}_{3} \mathrm{x}_{6}-1.48 \mathrm{x}_{4} \mathrm{x}_{5}-0.89 \mathrm{x}_{4} \mathrm{x}_{6} \\
& 1.66 \mathrm{x}_{5} \mathrm{x}_{6}-1.81 \mathrm{x}_{1}^{2}+0.33 \mathrm{x}_{2}^{2}-3.79 \mathrm{x}_{3}^{2}-2.31 \mathrm{x}_{4}^{2} \\
& -1.93 x_{5}^{2}-0.65 x_{6}^{2} \\
& \mathrm{y}_{2}=2.31-0.098 \mathrm{x}_{1}+0.57 \mathrm{x}_{2}+0.73 \mathrm{x}_{3}+0.078 \mathrm{x}_{4} \\
& +1.00 \mathrm{x}_{5}+0.41 \mathrm{x}_{6}-0.073 \mathrm{x}_{1} \mathrm{x}_{2}-0.021 \mathrm{x}_{1} \mathrm{x}_{3}+0.19 \mathrm{x}_{1} \mathrm{x}_{4} \\
& +0.068 \mathrm{x}_{1} \mathrm{x}_{5}+0.057 \mathrm{x}_{1} \mathrm{x}_{6}+0.14 \mathrm{x}_{2} \mathrm{x}_{3}+0.035 \mathrm{x}_{2} \mathrm{x}_{4} \\
& +0.24 \mathrm{x}_{2} \mathrm{x}_{5}+0.35 \mathrm{x}_{2} \mathrm{x}_{6}-0.15 \mathrm{x}_{3} \mathrm{x}_{4}+0.17 \mathrm{x}_{3} \mathrm{x}_{5} \\
& +0.11 \mathrm{x}_{3} \mathrm{x}_{6}+0.051 \mathrm{x}_{4} \mathrm{x}_{5}+0.061 \mathrm{x}_{4} \mathrm{x}_{6}+0.019 \mathrm{x}_{5} \mathrm{x}_{6}-0.12 \mathrm{x}_{1}^{2} \\
& -0.071 \mathrm{x}_{2}^{2}-0.059 \mathrm{x}_{3}^{2}-0.063 \mathrm{x}_{4}^{2}+0.069 \mathrm{x}_{5}^{2}-0.024 \mathrm{x}_{6}^{2}(7) \\
& \mathrm{y}_{3}=0.087+0.0035 \mathrm{x}_{1}-0.00233 \mathrm{x}_{2}+0.026 \mathrm{x}_{3}-0.00325 \mathrm{x}_{4} \\
& +0.017 \mathrm{x}_{5}+0.013 \mathrm{x}_{6} \\
& \mathrm{y}_{4}=0.39+0.007 \mathrm{x}_{1}-0.004 \mathrm{x}_{2}+0.12 \mathrm{x}_{3}+0.036 \mathrm{x}_{4} \\
& +0.097 \mathrm{x}_{5}+0.065 \mathrm{x}_{6}-0.00769 \mathrm{x}_{1} \mathrm{x}_{2}+0.021 \mathrm{x}_{1} \mathrm{x}_{3} \\
& +0.021 \mathrm{x}_{1} \mathrm{x}_{4}+0.033 \mathrm{x}_{1} \mathrm{x}_{5}+0.0068 \mathrm{x}_{1} \mathrm{x}_{6}+0.00819 \mathrm{x}_{2} \mathrm{x}_{3} \\
& +0.00944 \mathrm{x}_{2} \mathrm{x}_{4}-0.00194 \mathrm{x}_{2} \mathrm{x}_{5}+0.018 \mathrm{x}_{2} \mathrm{x}_{6}-0.022 \mathrm{x}_{3} \mathrm{x}_{4} \\
& +0.014 \mathrm{x}_{3} \mathrm{x}_{5}+0.011 \mathrm{x}_{3} \mathrm{x}_{6}-0.026 \mathrm{x}_{4} \mathrm{x}_{5} \\
& -0.0073 \mathrm{x}_{4} \mathrm{x}_{6}+0.011 \mathrm{x}_{5} \mathrm{x}_{6}
\end{aligned}
$$




\begin{tabular}{|c|c|c|c|c|}
\hline \multicolumn{5}{|c|}{$\begin{array}{c}\text { TABLE-2 } \\
\text { ESTIMATED REGRESSION COEFFICIENTS } \\
\text { AND CORRESPONDING F AND P VALUES } \\
\text { FOR SILICA REMOVAL EFFICIENCY }\end{array}$} \\
\hline Term & Coefficient & Sum of squares & $\mathrm{F}$ & Prob $>F$ \\
\hline Intercept & 97.85 & - & - & - \\
\hline $\mathrm{x}_{1}$ & -1.56 & 19.59 & 1.87 & 0.2298 \\
\hline $\mathrm{x}_{2}$ & 1.23 & 12.18 & 1.16 & 0.3303 \\
\hline $\mathrm{x}_{3}$ & 9.49 & 720.67 & 68.77 & 0.0004 \\
\hline $\mathrm{x}_{4}$ & 6.53 & 340.92 & 32.53 & 0.0023 \\
\hline $\mathrm{x}_{5}$ & 4.58 & 167.99 & 16.03 & 0.0103 \\
\hline $\mathrm{x}_{6}$ & 1.74 & 24.35 & 2.32 & 0.1880 \\
\hline $\mathrm{x}_{1} \mathrm{x}_{2}$ & 0.81 & 10.46 & 1.00 & 0.3637 \\
\hline $\mathrm{x}_{1} \mathrm{x}_{3}$ & 2.04 & 66.87 & 6.38 & 0.0528 \\
\hline $\mathrm{x}_{1} \mathrm{x}_{4}$ & -0.43 & 1.00 & 0.096 & 0.7696 \\
\hline $\mathrm{x}_{1} \mathrm{x}_{5}$ & 0.13 & 0.094 & 0.008977 & 0.9282 \\
\hline $\mathrm{x}_{1} \mathrm{x}_{6}$ & 0.030 & 0.015 & 0.00139 & 0.9717 \\
\hline $\mathrm{x}_{2} \mathrm{x}_{3}$ & -0.84 & 3.76 & 0.36 & 0.5751 \\
\hline $\mathrm{x}_{2} \mathrm{x}_{4}$ & -0.11 & 0.20 & 0.019 & 0.8955 \\
\hline $\mathrm{x}_{2} \mathrm{x}_{5}$ & 0.16 & 0.42 & 0.040 & 0.8493 \\
\hline $\mathrm{x}_{2} \mathrm{x}_{6}$ & 1.01 & 5.45 & 0.52 & 0.5030 \\
\hline $\mathrm{x}_{3} \mathrm{x}_{4}$ & -4.43 & 314.20 & 29.98 & 0.0028 \\
\hline $\mathrm{x}_{3} \mathrm{x}_{5}$ & -2.00 & 64.27 & 6.13 & 0.0561 \\
\hline $\mathrm{x}_{3} \mathrm{x}_{6}$ & 0.48 & 1.21 & 0.12 & 0.7483 \\
\hline $\mathrm{x}_{4} \mathrm{x}_{5}$ & -1.48 & 11.75 & 1.12 & 0.3381 \\
\hline $\mathrm{x}_{4} \mathrm{x}_{6}$ & -0.89 & 12.68 & 1.21 & 0.3215 \\
\hline $\mathrm{x}_{5} \mathrm{x}_{6}$ & -1.66 & 44.32 & 4.23 & 0.0949 \\
\hline $\mathrm{x}_{1}{ }^{2}$ & -1.81 & 98.76 & 9.42 & 0.0278 \\
\hline $\mathrm{x}_{2}^{2}$ & 0.33 & 3.37 & 0.32 & 0.5950 \\
\hline $\mathrm{x}_{3}{ }^{2}$ & -3.79 & 433.55 & 41.37 & 0.0013 \\
\hline $\mathrm{x}_{4}{ }^{2}$ & -2.31 & 161.06 & 15.37 & 0.0112 \\
\hline $\mathrm{x}_{5}^{2}$ & -1.93 & 112.53 & 10.74 & 0.0220 \\
\hline $\mathrm{x}_{6}{ }^{2}$ & -0.65 & 12.63 & 1.20 & 0.3224 \\
\hline
\end{tabular}

TABLE-3

ESTIMATED REGRESSION COEFFICIENTS AND CORRESPONDING F AND P VALUES FOR ENERGY CONSUMPTION

\begin{tabular}{|c|c|c|c|c|}
\hline Term & Coefficient & Sum of squares & $\mathrm{F}$ & Prob $>F$ \\
\hline Intercept & 2.31 & - & - & - \\
\hline $\mathrm{x}_{1}$ & -0.098 & 0.077 & 2.83 & 0.1531 \\
\hline $\mathrm{x}_{2}$ & 0.57 & 2.64 & 97.49 & 0.0002 \\
\hline $\mathrm{x}_{3}$ & 0.73 & 4.28 & 157.92 & $<0.0001$ \\
\hline $\mathrm{x}_{4}$ & 0.078 & 0.049 & 1.82 & 0.2353 \\
\hline $\mathrm{x}_{5}$ & 1.00 & 8.00 & 295.13 & $<0.0001$ \\
\hline $\mathrm{x}_{6}$ & 0.41 & 1.37 & 50.46 & 0.0009 \\
\hline $\mathrm{x}_{1} \mathrm{x}_{2}$ & -0.073 & 0.086 & 3.16 & 0.1355 \\
\hline $\mathrm{x}_{1} \mathrm{x}_{3}$ & -0.021 & 0.0069 & 0.26 & 0.6346 \\
\hline $\mathrm{x}_{1} \mathrm{x}_{4}$ & 0.19 & 0.19 & 7.10 & 0.0447 \\
\hline $\mathrm{x}_{1} \mathrm{x}_{5}$ & 0.068 & 0.025 & 0.92 & 0.3812 \\
\hline $\mathrm{x}_{1} \mathrm{x}_{6}$ & 0.057 & 0.052 & 1.91 & 0.2252 \\
\hline $\mathrm{x}_{2} \mathrm{X}_{3}$ & 0.14 & 0.11 & 3.94 & 0.1041 \\
\hline $\mathrm{x}_{2} \mathrm{x}_{4}$ & 0.035 & 0.020 & 0.72 & 0.4347 \\
\hline $\mathrm{x}_{2} \mathrm{x}_{5}$ & 0.24 & 0.94 & 34.84 & 0.0020 \\
\hline $\mathrm{x}_{2} \mathrm{X}_{6}$ & 0.35 & 0.65 & 23.85 & 0.0045 \\
\hline $\mathrm{x}_{3} \mathrm{x}_{4}$ & -0.15 & 0.38 & 14.03 & 0.0133 \\
\hline $\mathrm{X}_{3} \mathrm{X}_{5}$ & 0.17 & 0.48 & 17.73 & 0.0084 \\
\hline $\mathrm{x}_{3} \mathrm{x}_{6}$ & 0.11 & 0.062 & 2.30 & 0.1900 \\
\hline $\mathrm{x}_{4} \mathrm{x}_{5}$ & 0.051 & 0.014 & 0.51 & 0.5059 \\
\hline $\mathrm{x}_{4} \mathrm{x}_{6}$ & 0.061 & 0.059 & 2.18 & 0.1996 \\
\hline $\mathrm{x}_{5} \mathrm{x}_{6}$ & 0.019 & 0.00597 & 0.22 & 0.6587 \\
\hline $\mathrm{x}_{1}^{2}$ & -0.12 & 0.42 & 15.47 & 0.0110 \\
\hline $\mathrm{x}_{2}^{2}$ & -0.017 & 0.15 & 5.66 & 0.0632 \\
\hline $\mathrm{x}_{3}{ }^{2}$ & -0.059 & 0.10 & 3.87 & 0.1064 \\
\hline $\mathrm{x}_{4}{ }^{2}$ & -0.063 & 0.12 & 4.48 & 0.0879 \\
\hline $\mathrm{x}_{5}^{2}$ & 0.069 & 0.14 & 5.33 & 0.0690 \\
\hline $\mathrm{x}_{6}{ }^{2}$ & -0.024 & 0.018 & 0.65 & 0.4557 \\
\hline
\end{tabular}

TABLE-4

ESTIMATED REGRESSION COEFFICIENTS

AND CORRESPONDING F AND P VALUES FOR ELECTRODE CONSUMPTION

\begin{tabular}{ccccc}
\hline Term & Coefficient & Sum of squares & $\mathrm{F}$ & Prob $>\mathrm{F}$ \\
\hline Intercept & 0.087 & - & - & - \\
$\mathrm{x}_{1}$ & 0.0035 & 0.000294 & 1.15 & 0.2943 \\
$\mathrm{x}_{2}$ & -0.00233 & 0.000131 & 0.51 & 0.4819 \\
$\mathrm{x}_{3}$ & 0.026 & 0.016 & 62.41 & $<0.0001$ \\
$\mathrm{x}_{4}$ & -0.00325 & 0.000254 & 0.99 & 0.3295 \\
$\mathrm{x}_{5}$ & 0.017 & 0.00728 & 28.37 & $<0.0001$ \\
$\mathrm{x}_{6}$ & 0.013 & 0.00406 & 15.80 & 0.0005 \\
\hline
\end{tabular}

\begin{tabular}{|c|c|c|c|c|}
\hline \multicolumn{5}{|c|}{$\begin{array}{c}\text { TABLE-5 } \\
\text { ESTIMATED REGRESSION COEFFICIENTS } \\
\text { AND CORRESPONDING F AND P VALUES FOR } \\
\text { SLUDGE PRODUCTION } \\
\end{array}$} \\
\hline Term & Coefficient & Sum of squares & $\mathrm{F}$ & Prob $>F$ \\
\hline Intercept & 0.39 & - & - & - \\
\hline $\mathrm{x}_{1}$ & 0.007 & 0.000392 & 0.67 & 0.4319 \\
\hline$x_{2}$ & -0.004 & 0.000128 & 0.22 & 0.6502 \\
\hline $\mathrm{x}_{3}$ & 0.12 & 0.12 & 211.40 & $<0.0001$ \\
\hline $\mathrm{x}_{4}$ & 0.036 & 0.010 & 17.36 & 0.0016 \\
\hline $\mathrm{x}_{5}$ & 0.097 & 0.075 & 127.15 & $<0.0001$ \\
\hline $\mathrm{x}_{6}$ & 0.065 & 0.034 & 56.95 & $<0.0001$ \\
\hline $\mathrm{x}_{1} \mathrm{x}_{2}$ & -0.007688 & 0.000946 & 1.61 & 0.2313 \\
\hline $\mathrm{x}_{1} \mathrm{x}_{3}$ & 0.021 & 0.00735 & 12.49 & 0.0047 \\
\hline $\mathrm{x}_{1} \mathrm{x}_{4}$ & 0.021 & 0.00228 & 3.88 & 0.0747 \\
\hline $\mathrm{x}_{1} \mathrm{x}_{5}$ & 0.033 & 0.00592 & 10.05 & 0.0089 \\
\hline $\mathrm{x}_{1} \mathrm{x}_{6}$ & 0.0068 & 0.000743 & 1.26 & 0.2854 \\
\hline $\mathrm{x}_{2} \mathrm{x}_{3}$ & 0.00819 & 0.000358 & 0.61 & 0.4523 \\
\hline $\mathrm{x}_{2} \mathrm{x}_{4}$ & 0.00944 & 0.00142 & 2.42 & 0.1481 \\
\hline $\mathrm{x}_{2} \mathrm{x}_{5}$ & -0.00194 & 0.00006 & 0.10 & 0.7554 \\
\hline $\mathrm{x}_{2} \mathrm{x}_{6}$ & 0.018 & 0.00164 & 2.79 & 0.1228 \\
\hline $\mathrm{x}_{3} \mathrm{x}_{4}$ & -0.022 & 0.0077 & 13.07 & 0.0041 \\
\hline $\mathrm{x}_{3} \mathrm{x}_{5}$ & 0.014 & 0.00322 & 5.47 & 0.0393 \\
\hline $\mathrm{x}_{3} \mathrm{x}_{6}$ & 0.011 & 0.00061 & 1.03 & 0.3310 \\
\hline $\mathrm{x}_{4} \mathrm{x}_{5}$ & -0.026 & 0.00369 & 6.27 & 0.0293 \\
\hline $\mathrm{x}_{4} \mathrm{x}_{6}$ & -0.0073 & 0.000856 & 1.45 & 0.2534 \\
\hline $\mathrm{x}_{5} \mathrm{x}_{6}$ & 0.011 & 0.00196 & 3.32 & 0.0955 \\
\hline
\end{tabular}

Models analyzing: Table- 6 shows the F-value of the models for silica removal efficiency, energy consumption, electrode consumption and sludge production are 17.13, 50.89, 18.20 and 49.87, respectively, which implied the models are significant. For all models, the values of Prob $>F$ are less than 0.0500 , indicating that terms are significant in all models. In this study, the values of adj $\mathrm{R}^{2}$ are 0.9315 for silica removal efficiency, 0.9768 for energy consumption, 0.7633 for electrode consumption and 0.9698 for sludge production which ensures a satisfactory adjustment of the model to the experimental data. The coefficient of variance $(\mathrm{CV})$ as the ratio of the standard error of estimate to the mean value of the observed response is a measure of reproducibility of the model. As shown in Table6 , the values of coefficient of variance for the four responses are $3.58,7.77,18.32$ and $6.18 \%$, respectively. A ratio of AP > 4 indicates that adequate model is desirable. Then the AP values in the study are $14.480,26.929,16.196$ and 32.132 for silica removal efficiency, energy consumption, electrode consumption and sludge production, respectively.

3D response surfaces of responses: The $3 \mathrm{D}$ response surfaces are generally the graphical representation of the regression equation. This representation shows the relative effects of any two variables when the remaining variables are 
TABLE-6

ANOVA RESULTS OF THE MODELS FOR THE FOUR RESPONSES

\begin{tabular}{|c|c|c|c|c|c|}
\hline Source & Degree of freedom & Sum of squares & Mean square & F value & Prob $>F$ \\
\hline \multicolumn{6}{|c|}{ Silica removal efficiency $(\%)^{\mathrm{a}}$} \\
\hline Model & 27 & 4845.80 & 179.47 & 17.13 & 0.0025 \\
\hline Residual & 5 & 52.40 & 10.48 & & \\
\hline Lack of fit & 1 & 52.38 & 52.38 & 12233.63 & $<0.0001$ \\
\hline Pure error & 4 & 0.017 & 0.004282 & & \\
\hline \multicolumn{6}{|c|}{ Energy consumption $\left(\mathrm{KWh} / \mathrm{m}^{3}\right)^{\mathrm{b}}$} \\
\hline Model & 27 & 37.25 & 1.38 & 50.89 & 0.0002 \\
\hline Residual & 0.14 & 5 & 0.027 & & \\
\hline Lack of fit & 0.13 & 1 & 0.13 & 260.18 & $<0.0001$ \\
\hline Pure error & 0.00205 & 4 & 0.000513 & & \\
\hline \multicolumn{6}{|c|}{ Electrode consumption $\left(\mathrm{kg} / \mathrm{m}^{3}\right)^{\mathrm{c}}$} \\
\hline Model & 6 & 0.028 & 0.00467 & 18.20 & $<0.0001$ \\
\hline Residual & 26 & 0.00667 & 0.000257 & & \\
\hline Lack of fit & 22 & 0.00654 & 0.000297 & 8.61 & 0.0246 \\
\hline Pure error & 4 & 0.000138 & 0.0000345 & & \\
\hline \multicolumn{6}{|c|}{ Sludge production $\left(\mathrm{kg} / \mathrm{m}^{3}\right)^{\mathrm{d}}$} \\
\hline Model & 21 & 0.62 & 0.029 & 49.87 & $<0.0001$ \\
\hline Residual & 11 & 0.00648 & 0.000589 & & \\
\hline Lack of fit & 7 & 0.00643 & 0.000919 & 81.33 & 0.0004 \\
\hline Pure error & 4 & 0.0000452 & 0.0000113 & 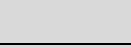 & \\
\hline
\end{tabular}

kept constant. The response surface plots are given in Fig. 2 for the silica removal efficiency, Fig. 3 for energy consumption and Fig. 4 for sludge production. For the linear relationship between electrode consumption and the variables, here presents no 3D response surfaces for electrode consumption.

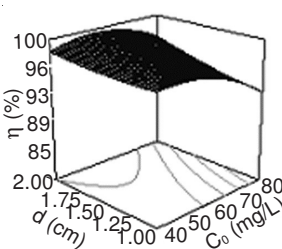

(a)

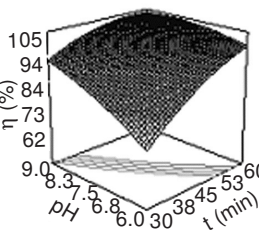

(b)

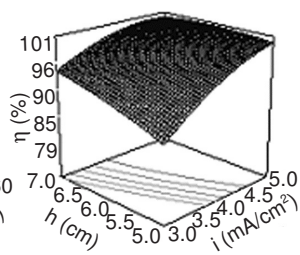

(c)
Fig. 2. 3D response surface graphs for interaction of variables on silica removal efficiency

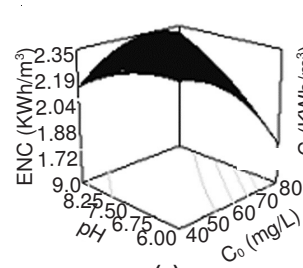

(a)

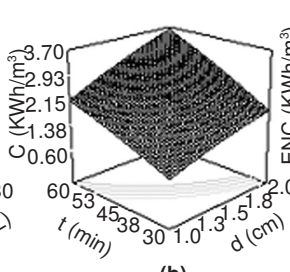

(b)

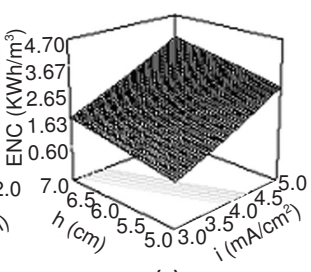

(c)
Fig. 3. 3D response surface graphs for interaction of variables on energy consumption

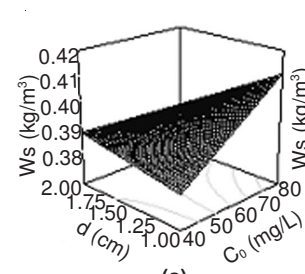

(a)

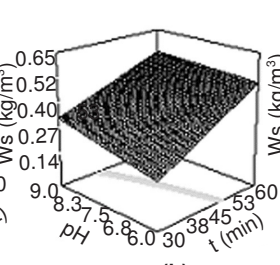

(b)

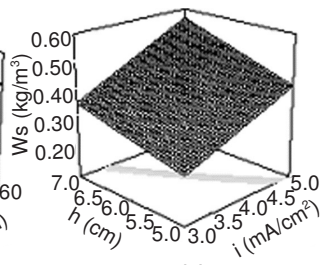

(c)
Fig. 4. 3D response surface graphs for interaction of variables on sludge production
Fig. 2(a) shows the effect of initial silica concentration and interelectrode distance on the silica removal efficiency when fixing the remaining variables at constant level. The response has little change with interelectrode distance, indicating that the other variables sufficient to ensure high removal efficiency. When interelectrode distance is about $1.4 \mathrm{~cm}$ and initial silica concentration is between 40 and $70 \mathrm{mg} / \mathrm{L}$, a region of more than $98 \%$ silica removal efficiency is obtained. A neutral value of $\mathrm{pH}$ and a long reaction time enable higher removal efficiency, according to Fig. 2(b). The $98 \%$ removal efficiency is attained in the range of $\mathrm{pH}$ from 9 to 6 and reaction time from 38 to $60 \mathrm{~min}$. It may because that larger mass of electrode was dissolved in the solution to combine with silica for a longer reaction time. The $\mathrm{pH}$ value plays an important role in electrocoagulation process, for the types and the formation rates of silica and $\mathrm{Al}$ species mainly depend on the $\mathrm{pH}$ value. The monomeric anion of $\mathrm{Al}(\mathrm{OH})_{4}{ }^{-}$will form when the $\mathrm{pH}$ is high and the soluble cation of $\mathrm{Al}^{3+}$ will form when $\mathrm{pH}$ is low $^{22}$. As shown in Fig. 2(c), the removal efficiency increases with the increase of current density and submerged height of electrode. The region of submerged height from 7 to 5 and current density from 3.9 to $4.5 \mathrm{~mA} / \mathrm{cm}^{2}$ ensures silica removal efficiency higher than $98 \%$. At higher current density and larger effective area, higher dissolution rates of electrode material and higher formation rates of aluminum hydroxides result in higher removal efficiency of silica.

From Fig. 3(a), higher $\mathrm{pH}$ and lower initial silica concentration or lower $\mathrm{pH}$ and higher initial silica concentration result in lower energy consumption. However, relatively higher $\mathrm{pH}$ leads to higher silica removal efficiency from Fig. 2(b). Therefore, the region with higher $\mathrm{pH}$ and lower initial silica concentration is desirable in the experiment. Energy consumption has a linear relationship with reaction time, interelectrode distance, current density and submerged height of electrode, according to the Fig. 3(b) and (c). Because of ENC $\propto$ UIt, the 
energy consumption is proportional to reaction time and current density. Increased distance between anode and cathode electrodes leads to increased voltage and then results in higher energy consumption ${ }^{23}$.

Amount of sludge produced during electrochemical treatment is of environment relevance. It points to the problem of solid waste generation and disposal costs associated with the process. Then the production of sludge is the less the better. Fig. 4(a) shows that higher initial silica concentration and smaller interelectrode distance result in higher sludge production. This may due to that more formation of hydroxyaluminosilicates $^{24}$ as eqn. 6 generated under these conditions.

$$
\begin{aligned}
\mathrm{nAl}^{3+} \stackrel{\mathrm{OH}^{-}}{\longleftrightarrow}\left[\mathrm{Al}(\mathrm{OH})_{3}\right]_{\mathrm{n}} \\
\stackrel{\mathrm{Si}(\mathrm{OH})_{4}}{\longleftrightarrow}(\mathrm{AlO})_{\mathrm{n}}(\mathrm{SiO})_{\mathrm{n} / 2}(\mathrm{OH})_{2 \mathrm{n}}
\end{aligned}
$$

Fig. 4(b) and (c) indicate that sludge production increases with the increase of $\mathrm{pH}$, reaction time, current density and submerged height of electrode in linear speed, for more formation of hydroxyaluminosilicates which mean that more silica was removed under these conditions.

Optimization of responses: The Design-Expert software can be used to optimize the experimental results, on the basis of the operator's requirements to achieve different project purposes. The software can give different solutions when different ranges of variables or different goals of responses are set. Since each kind of target water has established silicon concentration, here initial silica concentration is targeted at $60 \mathrm{mg} / \mathrm{L}$ as a representative. The $\mathrm{pH}$ value of target water is generally neutral and is targeted at 7.5. Then the other variables are set in range. For the responses, silica removal efficiency is to be maximized, energy consumption is to be minimized, electrode consumption is to be minimized and sludge production is to be minimized. For the purpose of silica removal, the importance of silica removal efficiency is set at III and the other three are set at II. Then one of the optimized conditions under these specified limits is $60 \mathrm{mg} / \mathrm{L}$ of initial silica concentration, 2.50 $\mathrm{cm}$ of interelectrode distance, $40.47 \mathrm{~min}$ of reaction time, 7.50 of $\mathrm{pH}$ value, $3.89 \mathrm{~mA} / \mathrm{cm}^{2}$ of current density and $4 \mathrm{~cm}$ of submerged height of electrode. At the optimum condition, $85.147 \%$ of silica removal efficiency, $1.455 \mathrm{KWh} / \mathrm{m}^{3}$ of energy consumption, $0.0389 \mathrm{~kg} / \mathrm{m}^{3}$ of electrode consumption and $0.242 \mathrm{~kg} / \mathrm{m}^{3}$ of sludge production are foreseen by the program optimization and the desirability is 0.831 . The verification of these results using the optimized conditions was accomplished by performing the experiments. And the actual results were obtained as follow: $83.243 \%$ of silica removal efficiency, 1.466 $\mathrm{KWh} / \mathrm{m}^{3}$ of energy consumption, $0.0400 \mathrm{~kg} / \mathrm{m}^{3}$ of electrode consumption and $0.245 \mathrm{~kg} / \mathrm{m}^{3}$ of sludge production.

\section{Conclusion}

The present study clearly demonstrated the applicability of electrocoagulation process using alminium electrode for silica removal from cooling water. It was showed that RSM is one of the suitable methods to optimize the operating factors to maximize silica removal efficiency and minimize energy consumption, electrode consumption and sludge production. The experimental results showed that satisfactory empirical model equations were developed for these variables. The interactions of the variables were demonstrated and reaction time and current density were the two main factors affecting the four responses seriously. The optimum conditions were also foreseen by the process software, which provided a better selection for practical application. And these were verified by preforming the optimum conditions.

\section{REFERENCES}

1. K.D. Demadis and E. Mavredaki, Environ. Chem. Lett., 3, 127 (2005).

2. C.H. Koo, A.W. Mohammad and F Suja, Desalination, 271, 178 (2011).

3. Y.D. Pan, F.Q. Si, Z.G. Xu and C.E. Romero, Powder Technol., 210, 150 (2011).

4. B.E. Lee, C.A.J. Fletcher, S.H. Shin and S.B. Kwon, Fuel, 81, 2001 (2002).

5. E. Mavredaki, E. Neofotistou and K.D. Demadis, Ind. Eng. Chem. Res., 44, 7019 (2005).

6. I. Nishida, Y. Shimada, T. Saito, Y. Okaue and T. Yokoyama, J. Colloid Interf. Sci., 335, 18 (2009).

7. K. Hiroeatari, Geothermics, 25, 259 (1996).

8. Y. Zeng, C.Z. Yang, W.H. Pu and X.L. Zhang, Desalination, 216, 147 (2007).

9. C.H. Koo, A.W. Mohammad and F. Suja, Desalination, 271, 178 (2011).

10. W. Den and C.J. Wang, Sep. Purif. Technol., 59, 318 (2008).

11. R. Sheikholeslami and J. Bright, Desalination, 143, 255 (2002).

12. A.M. Al-Rehaili, Desalination, 159, 21 (2003).

13. I. Bremere, M. Kennedy, S. Mhyio, A. Jaljuli, G.J. Witkamp and J. Schippers, Desalination, 132, 89 (2000).

14. A. Akyol, Desalination, 285, 91 (2012).

15. L. Li, C.M. van Genuchten, S.E.A. Addy, J.J. Yao. N.Y. Gao and A.J. Gadgil, Environ. Sci. Technol., 46, 12038 (2012).

16. D.R. Arsand, K. Kummerer and A.F. Martins, Sci. Total Environ., 443, 351 (2013).

17. L. Smoczynski, K. Munska and B. Pierozynski, Water Sci. Technol., 67, 404 (2013).

18. S.L. Gelover-Santiago, S. Perez-Castrejon and A. Martin-Dominguez, Water Sci. Technol., 65, 434 (2012).

19. Z. Liao, Z. Gu, M.C. Schulz, J.R. Davis, J.C. Baygents and J. Farrell, Water Sci. Technol., 60, 2345 (2009).

20. J.S. Do and M.L. Chen, J. Appl. Electrochem., 24, 785 (1994).

21. J.F. Martínez-Villafane, C. Montero-Ocampo and A.M. García-Lara, J. Hazard. Mater., 172, 1617 (2009).

22. M. Kobya, E. Demirbas, M. Bayramoglu and M.T. Sensoy, Water Air Soil Pollut., 215, 399 (2011).

23. M. Malakootian, H.J. Mansoorian and M. Moosazadeh, Desalination, 255, 67 (2010).

24. C. Exley and J.D. Birchall, Polyhedron, 12, 1007 (1993). 